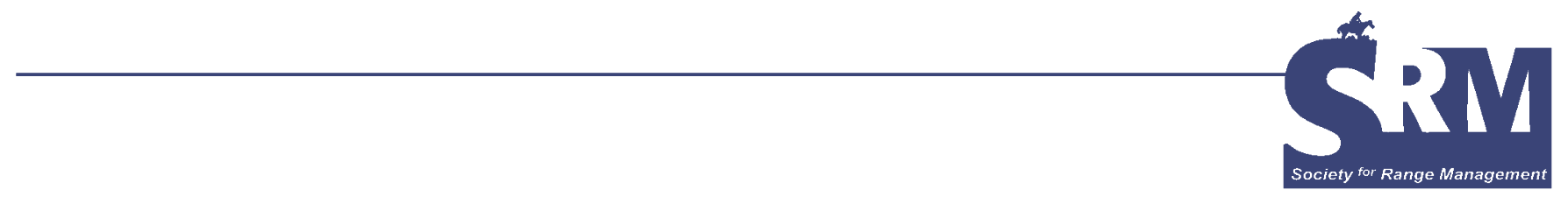

\title{
Eleventh in a Series: Insight From SRM's Charter Members
}

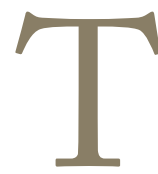
he SRM History Committee has conducted interviews with many of the Society's Charter Members to capture their perspective of events leading to and subsequent to the formation of the American Society of Range Management in 1947-1948. Interviews from several of these individuals will be shared for today's SRM members to enjoy and learn from.

\section{SRM Charter Member - John Morris Fenley Editor's Note: John Morris Fenley, 1745 Eldena Way \#116, Modesto, CA 95350-3570, a retirement center, has had a most interesting career, and this synopsis can only briefly relate it. A complete transcript can be made available on request. \\ John Fenley received a BS in 1939 from the University of} California, Berkeley, in Forestry and Range Management. He started university at UCLA in civil engineering, but after a summer's work in northern New Mexico on a sheep grazing problem (poisoning by pingue), he changed majors, and after completing the basic course work at UCLA transferred to Berkeley. He also holds an MS in range management and forestry from UCB in 1948 and a $\mathrm{PhD}$ in extension education from Cornell University in 1958.

John started work on his MS at the University of California, Berkeley, but could not complete it until after the war; he served in the Army from 1942 to 1946 . He transferred from the Soil Conservation Service at Lakeport, California, in 1946 to the Intermountain Forest and Range Experiment Station stationed at the Great Basin Research Center in Ephraim, Utah, under Perry Plummer. At the Great Basin station, he was a range ecologist, ultimately to be stationed in Nevada, as he was in Ephraim for training in range reseeding techniques. In the late fall of 1947, with several other technicians in Ephraim, he attended Regional meetings in Ogden, Utah, to organize what turned out to be the range management society. Joe Pechanec of the Pacific
Northwest Forest Service Region chaired that meeting. Interest was immediate and overwhelmingly sufficient for the American Society of Range Management (ASRM) to be formed. The Society was to become a living entity.

John's research location was in Paradise Valley, Humboldt County, Nevada, and he was transferred there in late 1947. During winter, he was living in Ogden and was able to attend the first meeting of the ASRM in January 1948. John was able to obtain a leave of absence and complete his MS at Berkeley under the GI Bill of Rights in June 1948. He and his wife, Eileen, returned to begin his range reseeding research activities in Nevada. John and Eileen's 3 children, Janice, Rick, and Molissa, were born in Nevada in 1948, 1951, and 1954, respectively.

In 1949, the Nevada range people organized the Nevada Section of the ASRM, and John was elected to be the Section's first secretary-treasurer. In 1950, John's work assignment office was on the University of Nevada campus, although he continued the fieldwork at Paradise Valley. In July 1951, because of his working relationships there on the Reno campus, he was offered and accepted an extension position at Las Vegas. He was vice president of the Section at that time. At their 1951 annual meeting in Caliente, he was elected Section president. He represented the Nevada Section at the ASRM annual meetings in Albuquerque in 1953 and San Jose in 1954. John has been a member of the Nevada Section from 1949 to 1963 and a member of the California Section since then. He also is an honorary member of the Nevada Section since 2001.

In 1955, John had the opportunity to take a leave of absence and be one of 13 Fellows in the Comparative Extension Seminar sponsored by a Ford Foundation grant and offered at Cornell University. John was accepted as a $\mathrm{PhD}$ candidate. He completed his degree in 1958 and was offered a teaching position to handle new groups of Seminar 
Fellows and teach graduate-level extension courses as well as guide $\mathrm{MS}$ and $\mathrm{PhD}$ students there at Cornell.

While at Cornell, John's wife, Eileen, was diagnosed with multiple sclerosis. Their 3 children were pressed into more intensive family responsibilities. Both John's increasing university workload and responsibilities at home required some changes. In 1961, John reluctantly resigned his Cornell position to take a new position with the U.S. State Department, Agency for International Development (USAID) in Nigeria teaching extension education. After his first 2 years teaching at the Western Region School of Agriculture, he worked as the regional extension officer and then as regional agricultural officer for 2 years. The next two 2-year assignments were in Nigeria's capital, Lagos, as country extension adviser, assisting and teaching about 30 US extension advisers. Following this, he was eligible for a 2-year rotational assignment to the United States and went to the Federal Extension Service in Washington, DC. Home care in the United States was much more expensive than in Africa, and in time John became employed by the Food and Agricultural Organization (FAO) of the United Nations in Liberia as an extension adviser. He was able to retain retirement privileges with USAID. His second tour of duty with the FAO was in Somalia with a subsequent tour in Sierra Leone. Living conditions in those parts of Africa were getting much less pleasant, so after that tour he retired and returned to their home in San Diego, California. They spent a total of 16 years in Africa.

John remarks that his employers always had supported his activities and involvement with the Society. He has never stopped paying dues since the beginning and feels proud to be an SRM member and supporting the Society's objectives.

\section{SRM Charter Member - Paul Krause}

Editor's Note: Paul Krause, Ridgewind Assisted Living, Room 301, 4080 Hawthorne Rd, Rogerson, ID 83302. Paul Krause was interviewed in January 2004 by Paul Butler, Caribou National Forest. Paul's daughter, Karen Barber, 10315 S Lava West Dr, Lava Hot Springs, ID 83246, (208) 776-5863, was also in attendance. This synopsis is abstracted from the tape.

Paul was born in 1913. He went to the University of Montana working his way through school and received a BS in 1939. His career was spent with the Bureau of Indian Affairs (BIA) in several locations. He took the civil service exam, ranking eighth in the nation and sixth in Montana as well as taking several unassembled exams. His first job was in Enumclaw, Washington, with the US Army Corps of Engineers for $\$ 1,440$ per year as an engineering aide. He wished to work in resource management, and shortly he got an offer to go with the BIA in Carson City, Nevada. However, when he and his wife got there, the housing to be used was not completed, so he was sent to Salt Lake City on temporary assignment doing resource inventories on several of the reservations in the Great Basin.

When those were near completion, he was sent to the Duck Valley reservation 100 miles north of Elko, Nevada, half in Nevada and half in Idaho. He related that the superintendent there was ordered by Washington, DC, to take him as the first range man. The man was virtually inhospitable to Paul and his small family and would not even let him come to staff meetings! In time, Paul was able to wangle a transfer from Duck Valley to Ft. Duchesne, Utah. His Salt Lake City boss apparently had no choice but to send Paul to Duck Valley, but was able to rectify that.

Paul was on the Ute Indian Reservation at Ft. Duchesne, Utah, 160 miles east of Salt Lake City, as branch chief for forestry and range management for the BIA. He worked with the Tribal Council and had 3 Indian range aides out on the 3 major divisions of the tribal land. He remarked that it was good duty. From there, he was sent to be a range man on one of the 5 major divisions of the big ( 15 million acres) Navajo reservation. Each of 5 men had about 3 million acres. Then he got appointed to be superintendent of one of those 5 , the one he was working in, for about 4 years. The previous superintendent apparently was "a real boss, a stickler for detail." Paul was told by staff that they were glad to have a real person in the job. That also was good duty.

Paul joined the Society of American Foresters early on before the American Society of Range Management (ASRM) was started. He found out about the formation of ASRM from his contact with his old professor, Mel Morris. He had kept in contact with him after he graduated. He was working on the Navajo reservation as the head range man, and Professor Morris would take range juniors on a range tour in the West/Southwest. Paul would meet them on the west side of the Navajo reservation at the Cameron Trading Post and show them what was going on in the way of range management. The reservation was four-fifths in Arizona and onefifth in New Mexico and about 200,000 acres in southeastern Utah. Professor Morris told him about ASRM being formed.

Paul did attend the first meeting of ASRM in Salt Lake City. His recollections of the meeting are as follows: "Quite a few of us were meeting in January 1948 in the Federal Building at Salt Lake City, and Joe Pechanec, of the Dubois Experiment Station, was in charge. He asked for 'all you guys interested in a range management organization to raise their hands,' and most did. So, he said, 'let's go across the street to the Newhouse Hotel and meet.' So, I am a real charter member." He was quite interested in joining ASRM and being involved. He was pleased that ASRM was a separate group and not a subsidiary of the Society of American Foresters. He remarked that when he got out of school, there was no source of information except periodic government bulletins and that formation of ASRM would bring research information to the fore in ways it had not been in the past.

Then he was transferred to Bemidji, Minnesota, for all the Indian reservations in Minnesota and 3 little reservations in northeastern Nebraska. He said that was rough duty, as there were many Indians and very little land on a number of reservations, 8 in Minnesota alone. They had to work for a living during the week, so they were able to have meetings 
only on weekends. In the summers, many Indians worked in the resorts on the many lakes there. People would come up there in droves from all over the country and stay for a week or so at resorts on lakes. This meant many weekend meetings, driving in snowstorms, and so on. One time he was traveling with a lawyer for one of the tribes when a blizzard grounded them. They holed up in a motel for 4 days before the storm eased up enough to let them out. Paul was there about 4 years.

Following that, he became the head range man for the big Navajo reservation at Window Rock, Arizona. That was good duty. His family lived in Arizona 20 miles from Gallup, New Mexico, as he covered the Arizona, New Mexico, and Utah area. He relates the first time he met with the Tribal Resources Committee. The chairman said, "I suppose you're

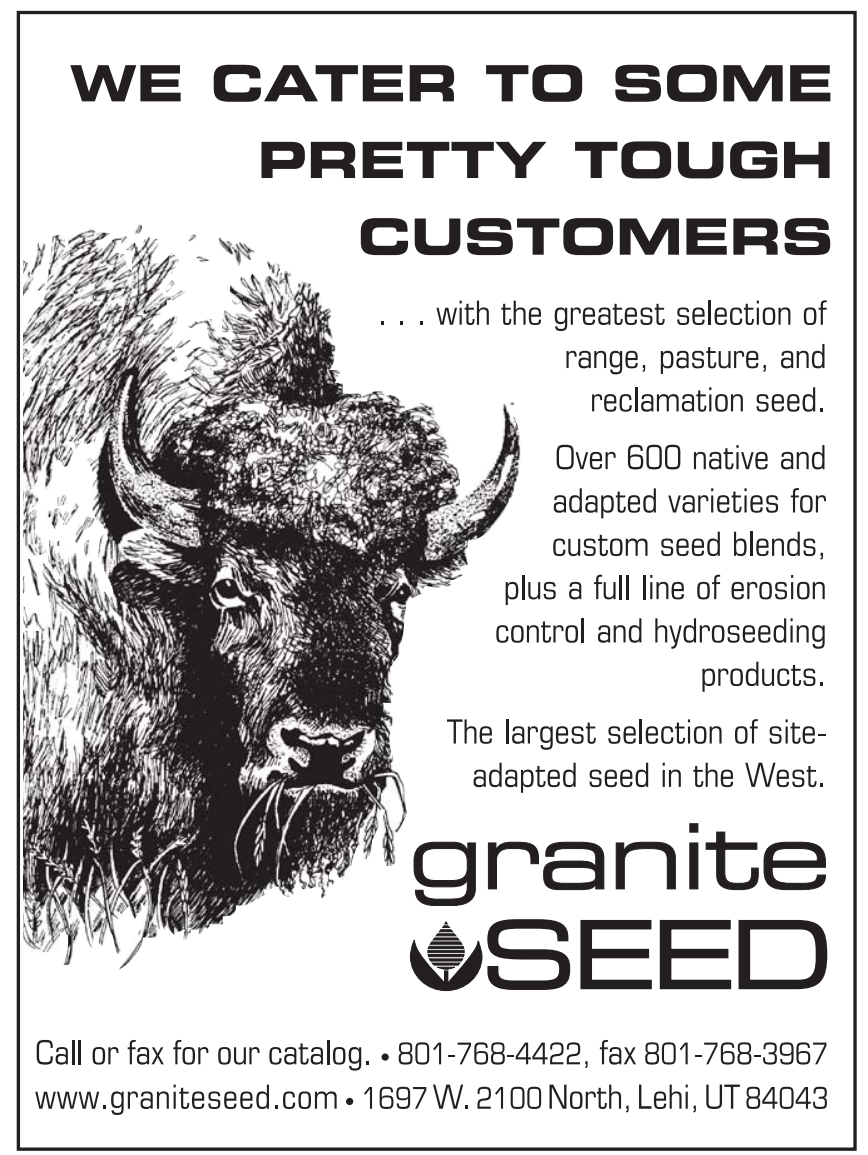

one of these young whippersnappers who are going to come in here and tell us Navajos how to run livestock, how to run sheep." Paul said, "No." He said, "Sheep are a tradition with us." Paul said, "Yeah, ever since the 1500s your ancestors swiped them from the Spanish conquistadores." He laughed and said, "You've read your history and done your homework. I suppose now you'll come down here and tell us how to run things." Paul said, "No, I know you know a lot of stuff, and I know a little bit. Let's put what we know together and see what happens." So they got along well. Paul was there for quite a while. He believes he must have been there in the early 1950s, as his daughter was in sixth grade when he went to Window Rock.

Eventually, he wound up in the area office in South Dakota, from where he retired. That position required a lot of traveling, but it was good duty. The man who was director retired about the time Paul got there, and they sent in a young man who was part Indian to take it over. He had been sent back to Washington, DC, for a couple of years to work all through the BIA system and wound up being appointed superintendent in South Dakota. He was one of 3 or 4 fellows who were deemed "most likely to succeed."

He knew Paul from his days in Minnesota. While there, Paul had a fight with one of the tribal councilmen on one of the reservations at Leech Lake, and the Indian was out to get Paul fired because he would not allow them to do things that were against federal regulations. And even their sons who would meet him on the streets would say, "Your days are numbered, Dad's going to run you out." Paul said to them, "You know what? He is telling so much stuff to the Minneapolis Trib and the TV over in Duluth that he was going to make me famous. One of these days I may be offered a real good job somewhere. You go tell that to him." Paul remarked that those were interesting times.

Paul retired in the late 1960s. He never held any ASRM offices and many times could not get to meetings. He needed to be on the program in order to get per diem to attend, and he said he wasn't well enough known to be on programs. He concludes by stating his belief that SRM has done well over the years and certainly met his expectations.

Tom Bedell is a member and former chairman of the SRM History Committee and a member of the Pacific Northwest Section living in Philomath, Oregon, tbedell@peak.org. 